Article

\title{
Serum Immunoglobulin-G Level In Children With Respiratory Tract Infection
}

\author{
Ahkter $\mathbf{S}^{1}$ Begum $\mathbf{N}^{2}$
}

Introduction- Acute respiratory tract infection is one of the important cause of death in children under 5 years of age in developing countries. Perhaps they have a reduced immunologic capacity. Objectives- To observe the serum IgG level in the children suffering from respiratory tract infection in order to evaluate the immunity status in this group of population. Study design- This cross-sectional study was conducted in the Department of Physiology, Bangabandhu Sheikh Mujib Medical University (BSMMU), Shahbagh, Dhaka from January to December 2001.Total 60 children age ranged from 35 years of both sexes were included in this study. Of them 30 apparently healthy children were considered as control and 30 children suffering from respiratory tract infection were considered as study group and further subdivided into 2 subgroups on the basis of presence of type of RTI. Group $\mathrm{B}_{1}$ consisted of 15 children with acute attack and $\mathrm{B}_{2}$ with recurrent attack. Method: Serum imunoglobulin $\mathrm{G}$ level of all the children were measured by Radial Immuno diffusion Method. Datawere analyzed by unpaired $t$ test. Result- The mean $( \pm S E)$ of serum IgG levels were $10.17 \pm 0.37,10.05 \pm$ 0.40 and $10.01 \pm 0.52 \mathrm{~g} / \mathrm{l}$ in control group and two study subgroups respectively. The data were almost similar in all the groups and no statistically significant( $>>0.05)$ differences were observed. Conclusion - This study reveals that there was no involvement of the IgG status with acute and recurrent respiratory tract infections in the children.

Keywords - Children, Respiratory tract infection, Immunoglobulin G.

J Bangladesh Soc Physiol.2008 Dec;(3):55-57. For author affiliations, see end of text.

http://www.banglajol.info/index.php/JBSP

\section{Introduction}

cute respiratory tract infection is one
of the important cause of death in
children under 5 years of age in developing countries ${ }^{1}$. A high proportion of this death is due to acute lower respiratory tract infections especially pneumonia ${ }^{2-3}$. Malnourished children appear to have a higher incidence of acute lower respiratory tract infection $^{4-5}$. Perhaps they have a reduced immunologic capacity. It is reported that attack of respiratory tract infection was more in immunodefient children than that of immunocompetent children ${ }^{6-9}$. It was observed

J Bangladesh Soc Physiol. 2008 Dec;(3):55-57 that lower level of serum IgG in children suffering from recurrent respiratory tract infection ${ }^{10}$. Again it was also found that there was no significant change in serum IgG level in children suffering from similar type of respiratory tract infection ${ }^{11}$. Acute respiratory tract infection is one of the important cause of morbidity and mortality in children under 5 years of age in developing countries like Bangladesh. Only a few data are available on immunity status in children with respiratory tract infection in our country 9 , 12. But serum IgG level is one of the common marker to observe the immunity status of any 
Article

individual. Therefore the present study has been designed to observe the serum IgG level in the children suffering from respiratory tract infection in order to evaluate the immunity status in this group of population.

\section{Methods}

This cross sectional study was carried out in the Department of Physiology, Bangabandhu Sheikh Mujib Medical University (BSMMU), Shahbagh, Dhaka from January to December 2001. For this purpose, a total number of 60 children of both sexes with age ranged from 3 to 5 years were taken from the relatives and the Out Patient Department (OPD) of Dhaka Shishu hospital. Among them, 30 apparently healthy children were taken as control (Group A) and 30 children suffering from respiratory tract infections (RTI) were selected as study group (Group B). The study group was further subdivided into 2 subgroups (each consisted of 15 children) on the basis of presence of type of RTI (with acute attack $\mathrm{B}_{1}$ and with recurrent attack $\mathrm{B}_{2}$ ). In the present study, patients of pneumonia (lower chest indrawing / increased respiratory rate more than age specific value) was considered as acute respiratory infection (RTI) and included and patients with bacterial infections other than RTI, diarrhoea, kidney diseases, malnutrition, any serious or prolonged illness and vaccinated in any time within 6 months were excluded from the study by taking history and clinical examinations. Estimation of IgG was done by Radial Immuno Diffusion (RID) method ${ }^{13}$ and data were compared among different groups of children. Statistical analysis of the data were done by using unpaired Students 't' test.

\section{Results}

Results are shown in table I.

The values of mean serum IgG levels among groups and subgroups were almost similar and their differences were not statistically significant.
IgG in Respiratory Tract infection

Table-I

Serum IgG levels in different study groups ( $\mathrm{n}=$ 60)

\begin{tabular}{lccl}
\hline Group/ & $\mathrm{n}$ & \multicolumn{2}{c}{ Serum IgG level $(\mathrm{g} / \mathrm{L})$} \\
Subgroup & & Range & Mean $( \pm \mathrm{SE})$ \\
\hline A & 30 & $6 . .90-14.50$ & $10.17 \pm 0.37$ \\
B1 & 15 & $7.60-14.50$ & $10.05 \pm 0.40$ \\
B2 & 15 & $6.50-12.70$ & $10.01 \pm 0.52$ \\
\hline
\end{tabular}

Statistical Analysis

\begin{tabular}{lccc}
\hline & df & t value & $\mathrm{P}$ \\
\hline A vs B1 & 43 & 0.112 & $>0.05^{\mathrm{NS}}$ \\
A vs B2 & 43 & 0.262 & $>0.05^{\mathrm{NS}}$ \\
B1 vs B2 & 28 & 0.111 & $>0.05^{\mathrm{NS}}$ \\
\hline
\end{tabular}

$\mathrm{A}=$ healthy children (control)

$\mathrm{B}_{1}=$ children with acute respiratory tract infection (experimental)

$\mathrm{B}_{2}=$ children with recurrent respiratory tract infection (experimental)

$\mathrm{n}=$ number of subjects.

$\mathrm{df}=$ Degree of freedom

NS $=$ Not significant

\section{Discussion}

In the present study, the serum IgG level (non specific) was measured to evaluate the status of immune response of the children suffering from acute and recurrent respiratory tract infection and these level were within normal range. These results are in agreement with those reported by other workers of different countries ${ }^{11}$. It has been suggested that decreased serum IgG level in children suffering from recurrent respiratory tract infection may be due to malnutritional changes in the immune system $^{10}$. The findings of the present study showed that serum IgG level was not affected in children with acute and recurrent respiratory tract infection. Measurement of specific serum Ig $\mathrm{G}$ after specific vaccination in children may be a more conclusive one.

J Bangladesh Soc Physiol. 2008 Dec;(3):55-57 


\section{Authors and affiliations}

*1. Salma Akhter, Assistant Professor. Department of Physiolgogy, Shahabuddin Medical College, Dhaka. Tele: +88-02-8053404,+88-01720426526

2. Noorzahan Begum,Chairman, Department of Physiology, Bangabandhu sheikh Mujib Medical University, (BSMMU) Dhaka.

* For correspondence

\section{References}

1. Bull A, Hitze KL. Acute respiratory infections; a review. WHO Bull. 1978; 1978 56(3):481-98,.

2. Pio A, Leowski J, Ten Dam HG. The magnitude of the problem of acute respiratory infection. In: Dogulas RM, Kerby-Eaton E (eds.). ARI in childhood proceedings of an International workshop. Ad Laide, Australia University of Adelaide.,Sydney, 1984; PP3-16.

3. Devy FW, Loda FA. Acute respiratory infections are the leading cause of death in children in developing country. Am J Trop Med Hgg 1986; 35:1-2.

4. Tapasi TE, Mangubal NV, Sunico ME, Megdangal DM, Navarro EE, Leonor Za et al. Malnutrition and acute respiratory tract infections in Filipino children. Rev Infect Dis 1990; 12(suppl): 1047-54.

5. James JW. Tongitudinal study of the morbidity of diarrheal and respiratory infections in malnourished children. Am J Clin. Nutr 1972;25:690-4.

6. Black EE, Lanata CF, Lazo F. Delayed cutaneous hypersensitivity; epiemiologic factors affecting and usefulness in predicting diarrheal incidence in young peruvian children. Pediatr infect Dis 1989;8:210-5.
7. Baqui AH, Black RE, Sack RB, Chowdhury HR, Yunus $\mathrm{M}$, Siddique AK. Malnutrition cell mediated immune deficiency and diarrhoea: a community-based longitutinal study in rural Bangladeshi children. Am J Epidemiol 1993;137:355-65.

8. Snell-Duncan B. Determinants of infant and childhood morbidity among Nomadic Tarkana Postoralists of North-West Kenya [Doctoral dissertation], Pennsylvania state University, USA, pp84-112, 1994.

9. Zaman K, Bagui AH, Yunus M, Sack RB, Baleman OM, Chowdhury HR et al. Association between nutritional status, cell mediated immune status and acute lower respiratory infections in Bangladeshi children. Eur J Clin Nutr 1996; 50: 309-14.

10. Gross S, Blaiss MS, Herrod HG. Role of immunoglobulin subclasses and specific antibody determinations in the evaluation of recurrent infection in children. J Pediatr 1992; 121(4): 516-22.

11. Berman S, Lee B, Nurs R, Roark R, Giclus PL. Immunoglobulin $\mathrm{G}$, total and subclass in children with or without recurrent otitis media. J Pediatr 1992; 121(2): 249-51.

12. Shakur S, Malek MA, Torafder SA. Zinc status of Bangladeshi children suffering from and respiratory infection. Orion 2000; 5: -7.

13. Fahey JL, McKelvey EM. Quantative determination of serum immunoglobulins in antibody agar plates. J Immunol 1965; 94: 84-90. 